\title{
Erratum
}

\section{Mutations in BHD and TP53 genes, but not in HNFI $\beta$ gene, in a large series of sporadic chromophobe renal cell carcinoma}

S Gad, SH Lefèvre, SK Khoo, S Giraud, A Vieillefond, V Vasiliu, S Ferlicot, V Molinié, Y Denoux, N Thiounn, Y Chrétien, A Méjean, M Zerbib, G Benoît, JM Hervé, G Allègre, B Bressac-de Paillerets, BT Teh and S Richard

British Journal of Cancer (2007) 96, I3|4. doi:10.1038/sj.bjc.6603733 www.bjcancer.com

(c) 2007 Cancer Research UK

Correction to: British Journal of Cancer (2006) 96, 336-340. doi:10.1038/6603492

Owing to a publishing error, part of the intended Supplementary Material for this paper was omitted at the time of publication. The correct supplementary tables were published; however, a further document was omitted. We are now happy to include this document as part of the Supplementary Material online - please visit the British Journal of Cancer website (http://www.nature.com/ bjc). 